THE SUBSIDY FROM STATE AND LOCAL TAX DEDUCTIBILITY: TRENDS, METHODOLOGICAL ISSUES, AND ITS VALUE AFTER FEDERAL TAX REFORM*

\author{
Robert Tannenwald
}

Federal Reserve Bank of Boston

Even though the momentum of the "devolution" movement has slowed, federal intergovernmental grants will probably be cut substantially during the next five to ten years. Federal tax reform could further erode federal assistance by eliminating the deduction for state and local personal income and property taxes. This deduction subsidizes the net cost to taxpayers of financing an additional dollar of state and local spending. In the language of economics, deductibility reduces the marginal "tax price" of state and local public goods.

This paper clarifies methodological issues in the estimation of this tax price, updates estimates of tax price by state, and evaluates the impact of state and local taxes on the level and dispersion of state-specific tax prices. The paper argues that previous estimates of tax reflect assumptions, often implicit, concerning the distribution of influence among consumers over the level of public goods provided by a given jurisdiction. These assumptions, often implicit, do not always square with the estimators' preferred theory concerning how the level of public goods is determined. Even when they do, they fail to take into account the deductibility of state and local business taxes from federal taxable profits. The estimates provided in this paper attempt to address these two problems.

*An earlier version of this paper was presented at the Allied Social Science Annual Meetings, New Orleans, January 6, 1997. The author would like to thank Bob Triest and Leonard Burman for helpful comments. 


\section{THE SUBSIDY FROM STATE AND LOCAL TAX DEDUCTIBILITY: TRENDS, METHODOLOGICAL ISSUES, AND ITS VALUE AFTER FEDERAL TAX REFORM}

Even though the momentum of the "devolution" movement has slowed, federal intergovernmental grants will probably be cut substantially during the next five to ten years. Federal tax reform could further erode federal assistance by eliminating the deduction for state and local personal income and property taxes. This deduction subsidizes the net cost to taxpayers of financing an additional dollar of state and local spending. In the language of economics, deductibility reduces the marginal "tax price" of state and local public goods (hereafter simply referred to as "tax price").

This paper clarifies methodological issues in the estimation of tax price, updates estimates of tax price by state, and evaluates the impact of eliminating deductibility of state and local taxes on the level and dispersion of state-specific tax prices.

\section{Methodological Issues in the Measurement of Tax Price}

In evaluating the impact of subsidization in private markets, one estimates the subsidy's initial effect on price and subsequent adjustments in supply and demand. The task is more complicated in the case of a publicly provided good because its price varies by consumer, and each consumer's bidding power reflects his or her political influence. For each consumer, therefore, one must determine the price faced and the consumer's ability to "bid" for goods in the public decision-making arena.

This task becomes much simpler if one can identify a "decisive decision-maker," whose response determines a jurisdiction's level of public spending. Knowledge of the 
"tax price" faced by the decision-maker and his or her price elasticity is sufficient to determine the impact of deductibility on the spending level. An example of such a decision-maker is the "median voter" hypothesized in some decision-making models. In these models, the distribution of preferences for the level of public spending is single-peaked. Under the assumption of majority rule, the preference of the voter at the 50th percentile in this distribution always prevails. ${ }^{1}$ A major obstacle to testing these models is identifying the median voter. Zimmerman (1983) defines the median voter as the person with the median pre-tax income. Gramlich (1985) infers the characteristics of the median voter from a 1978 survey of Michigan voters that included questions concerning income, itemizer status, and preferences concerning changes in the level of state and local spending.

Many scholars, dissatisfied with median voter models, have assumed that the "community as a whole" determines a jurisdiction's level of public spending. When attempting to determine deductibility's impact on the tax price faced by a "community," these scholars make assumptions, often implicit, about the distribution of political influence among members of the community or the mix of taxes used to finance marginal public spending. Sometimes these assumptions do not square with the author's preferred decision-making theory. Even when they do, they fail to take into account the deductibility of state and local business taxes from federal taxable profits.

${ }^{1}$ Inman (1986) reviews and critiques the median voter model, as well as several other applicable public decision-making models. Further theoretical discussion of the median voter model can be found in Borcherding and Deacon (1962) and Bergstrom and Goodman (1973). 
Consider, for example, the definition of average tax price used by Feldstein and Metcalf (1987) in their study of the impact of deductibility on the level of state and local total spending and the mix of state and local taxes:

$$
\mathrm{TP}_{\mathrm{av}}=1-\mathrm{p}+\mathrm{p}(1-\mathrm{m})=1-\mathrm{pm}
$$

where $p$ is the proportion of individuals who itemize and $m$ is the unweighted average federal marginal tax rate for a personal income tax filer. Since the authors estimate that this rate was 27 percent and the percentage of federal income tax filers who itemize was 30 percent in $1970, \mathrm{TP}_{\mathrm{av}}$ was $1-.27(.30)=\$ .92$. Their estimated statespecific tax prices range from a high of $\$ .97$ (South Dakota) to a low of $\$ .87$ (Alaska). The authors use this measure to estimate, among other things, the effect of federal tax price on aggregate state and local spending in each state. They equate aggregate spending with the sum of all general own-source revenues.

In their theoretical discussion, the authors imply a decision-making model in which households, both itemizers and non-itemizers, determine the level of public spending. Their definition of tax price further implies that marginal state and local spending is financed exclusively out of taxes paid by households that are deductible from federal taxable personal income. Otherwise (retaining for the moment their other assumption, that incremental spending is household-financed), their tax price definition would be:

$$
\mathrm{TP}_{\mathrm{av}}=1-\mathrm{dpm}
$$


where $d$ equals the proportion of state and local revenues raised from households that are deductible by households. Thus, if this proportion were one-half, the tax price in the above example would be $1-.5(.27)(.3)$ or $\$ .96$, not $\$ .92$. The authors' formula also implies that each federal income tax filer has equal ability to influence the level of state and local spending.

Even if households alone, without businesses, determine spending levels, it is implausible that incremental state and local spending is financed exclusively out of taxes deductible by households. Many taxes paid by households in 1979, such as selective excise taxes and license taxes, as well as all user fees and charges paid by households, were not deductible. State and local governments relied heavily on these non-deductible revenue sources in the late 1970s and early 1980s, especially given the particularly intense unpopularity of property taxation at that time.

According to Kenyon's (1986) formula, tax price is

$$
\mathrm{TP}_{\mathrm{av}}=1-h \mathrm{p}_{\mathrm{w}} \mathrm{m}_{\mathrm{w}}
$$

where $\mathrm{h}$ equals the percentage of taxes for which households are liable that are potentially deductible and the subscript $w$ indicates that the statistics were doubleweighted for joint filing units to reflect that they comprise two voters. In order to compute " $h$ " she relied on the U.S. Advisory Commission on Intergovernmental Relations' ( ACIR 1981) nationwide and state-specific estimates of the share of taxes nominally paid by households. ACIR took each tax levied by state and local governments and, for each state, estimated that fraction of each tax paid by 
households and the fraction paid by businesses. Thus, in 1982, when state and local personal income taxes, property taxes paid by households, and general sales taxes paid by households were deductible on individual income tax returns:

$$
h=\left(Y+P_{h h}+S_{h h}\right) / T_{h h}
$$

where $\mathrm{Y}=$ state and local personal income tax receipts

$$
\begin{aligned}
& P_{h h}=\text { state and local property taxes paid by households } \\
& S_{h h}=\text { state and local general sales taxes paid by households } \\
& T_{h h}=\text { all state and local taxes paid by households. }
\end{aligned}
$$

Equation 4 implicitly assumes first, that voters who file federal income tax returns determine the marginal level of state and local spending, and second, that incremental state and local spending is financed out of all taxes for which households are liable. For 1982 Kenyon computes a tax price of $\$ .91$, almost identical to Feldstein and Metcalf's \$.92. The two results are so similar because Kenyon's weighted "p"s and "m"s are higher than Feldstein and Metcalf's. (They are higher because married couples are more likely to itemize and have higher marginal tax rates.) The higher "p"s and "m"s roughly offset the effect of Kenyon's multiplying pm by the fraction $\mathrm{h}$.

While Kenyon's measure of tax price is an improvement over Feldstein's and Metcalf's, it still suffers from two drawbacks: 1) it assumes that each taxpaying unit has equal influence in determining the level of state and local spending, and 2) it takes no account of the impact on tax price of the deductibility of all state and local business 
taxes from federal taxable corporate profits. With respect to the first drawback, it seems more likely that a taxpayer's influence in setting a state's state-local spending level is proportional to the amount of state and local taxes that he or she pays. State and local tax bills go up with income, an important correlate of power (although tax bills do not go up proportionately with income, since the tax systems of most states are regressive). Arguably, a household's interest in the level of state and local spending rises with its tax bill; the higher the household's share of the tax bill, the higher its stake in the spending-level decision. In rebuttal, one could argue that the most powerful households are able to keep their tax bills low, forcing others to foot the bill. However, I would argue that weighting itemizers' federal marginal tax rates by the amount of state and local taxes paid provides a more accurate measure of tax price than weighting them equally or double-weighting joint filers.

With respect to the second drawback to Kenyon's measure, the deductibility of state and local business taxes has never been taken into account, for at least two reasons. First, models of state and local spending levels posit no role for businesses because firms do not vote. Yet, in determining the aggregate level of a state's state and local spending, businesses exert a powerful influence through lobbying, campaign contributions, and threats to move to other states. Perhaps businesses play little role at the local level, for example, in setting the size of a school district's budget (the median voter model was originally designed for local decision-making). At the state level, however, it is unrealistic to ignore their influence. 
Deductions for state and local taxes on business reduce the effective marginal burden of those taxes, just as comparable deductions do for state and local taxes on households. The reduction in marginal tax burden for businesses is potentially large, given that all business taxes are deductible and all businesses are in effect "itemizers," that is, they all deduct their taxes.

\section{Alternative Estimates of Tax Price Based on a New Methodology}

The following formula, set forth in Tannenwald (1989), addresses the two problems set forth above:

$$
\mathrm{TS}_{\mathrm{av}}=\mathrm{Bb}+(1-\mathrm{B})(\mathrm{S} / \mathrm{H})(\mathrm{Q} / \mathrm{S}) \mathrm{m}=\mathrm{Bb}+(1-\mathrm{B})(\mathrm{Q} / \mathrm{H})=\mathrm{Bb}+(\mathrm{Q} / \mathrm{T}) \mathrm{m}
$$

where:

$\mathrm{TS}_{\mathrm{av}}=$ the tax subsidy rate, or $1-$ tax price

$\mathrm{B}=$ share of state and local taxes for which businesses are liable

$\mathrm{b} \quad=$ the average marginal federal business profits tax rate

$\mathrm{S} \quad=$ taxes that are deductible by households

$\mathrm{H} \quad=$ the share of state and local taxes for which households are liable

$\mathrm{Q} \quad=$ taxes actually deducted by itemizers

$\mathrm{m} \quad=$ average marginal federal tax rate of itemizers weighted by state and local taxes deducted

$\mathrm{T} \quad=$ total state and local taxes.

The formula in effect says that, for any state, the household component of the tax subsidy rate is a function of households' share of taxes, the proportion of household taxes that is deductible, the percentage of household deductible taxes that is actually 
deducted, and the average federal tax savings per deducted tax dollar. The business component of the tax subsidy rate is equal to business's share of taxes times the average federal tax savings per deducted business tax dollar.

The formula implies that the influence of all taxpayers on the level of state and local spending, businesses as well as households, is proportional to the amount of tax they pay. This assumption is arbitrary. Ideally, the relative weights applied to the household and business components should be derived from an explicit model of the process by which the level of such spending is determined. The formula can be modified to incorporate whatever relative weights one feels are appropriate.

\section{Results for the Nation as a Whole}

Using this formula, I estimated the nationwide tax subsidy rate, as well as its household and business components, for 1977, 1980, 1985, 1988, and 1995. Sources

of data are described and further methodological details are explained in the Appendix. Results are presented in Figure 1 and Table 1.

As Figure 1 shows, the total tax subsidy rate is much higher--and, therefore, the tax price much lower--when the business component is taken into account. Indeed, the business component is greater than the household component in each of the five years examined except 1985. While the household component ranged from 10.0 percent to 6.7 percent, the total subsidy rate has ranged from 21.5 percent to 15.3 percent.

The total subsidy rate drifted downward from 1977 to 1985, dropped sharply between 1985 and 1988, and has since risen slightly. Several factors account for this pattern. 
1977 to 1985 . Between 1977 and 1985, the total subsidy rate declined from 21.5 percent to 19.4 percent because the business tax subsidy rate declined. The decline occurred largely because of a sharp drop in the average marginal federal corporate profits tax rate from 39.9 percent to 32.5 percent. $^{2}$ In 1977 the top federal statutory rate was 48 percent. By 1985 it was 46 percent, rates applicable to corporations with income of less than $\$ 100,000$ had been reduced, depreciation had been made more generous, and limitations on the investment tax credit had been relaxed. A decline in business's share of state and local taxes accentuated the decline in the business component.

During the same eight years, the household subsidy rate rose from 9.3 percent to 10 percent, thanks mostly to a large rise in households' propensity to itemize, from 26 percent to 39 percent (Table 1, column 8 ). This propensity rose so rapidly because average outlays per household for the largest deductible expenses--home mortgage interest, charitable contributions, and state and local taxes--rose much more than the standard deduction for federal single and joint tax filers (Figure 2). For example, while the standard deductions for single and joint filers rose by only 9 percent and 11 percent, respectively, between 1977 and 1985, the average monthly mortgage payment rose by 175 percent over the same period. Even the average payment per household of deductible state and local taxes rose by 90 percent, despite the fact that this period

\footnotetext{
${ }^{2}$ In theory the average marginal business tax rate, not the average marginal corporate tax rate, should be used. Since the former was not available, the latter was used as a proxy. Nationwide, corporations accounted for 97 percent of net business income reported on federal business tax returns in 1992 (U.S. Internal Revenue Service 1995a, 1995b).
} 
included the height of the "property tax revolt" and the elimination by Congress of the deductibility of state and local motor fuel taxes, in the Revenue Act of 1978.

Another factor moderating the increase in the household component during this period was a reduction in itemizers' average marginal federal income tax rate from 32.9 percent to 28.2 percent (Table 1, column 7 ). This reduction primarily reflects cuts in statutory rates. In 1977, there were 25 federal individual income tax brackets, ranging from 14 percent to 70 percent. The Economic Recovery Act of 1981 reduced the lower and upper bounds of this range to 11 percent and 50 percent, respectively, and the number of brackets to $14 .^{3}$ Inflation-induced "bracket creep" offset the effects of these rate reductions, however, contributing to the rise in the household component.

1985 to 1988 . During this period, the total subsidy rate fell by more than 4 percentage points because of the Tax Reform Act of 1986. The Act lowered federal corporate and individual income tax rates, eliminated the deductibility of general state and local sales taxes, and reduced the propensity to itemize. The top federal corporate income tax rate was reduced from 46 percent to 34 percent, cutting the average marginal rate from 32.5 percent to 26.7 percent. The number of federal personal income tax brackets was reduced to two, 15 percent and 28 percent. Largely as a result, itemizers' average marginal tax rate fell from 28.2 percent to 25.3 percent. The

${ }^{3}$ The rise in propensity to itemize also may have indirectly reduced the average marginal tax rate of itemizers. As outlays for deductible outlays rise faster than income, households in successively lower tax brackets switch from non-itemizer to itemizer status. See Clotfelter and Feenberg (1990). 
Act eliminated bracket creep by indexing the width of tax brackets, the personal exemption, and the standard deductions for inflation.

The Act reduced the propensity to itemize from 39 percent to 29 percent by eliminating or curtailing a wide array of deductions and exclusions (consumer interest, medical expenses, employee expenses, and, as noted above, state and local sales taxes) and raising the standard deductions for single and joint filers above their 1985 values by 26 percent and 41 percent, respectively. Moreover, growth in the average value of large, remaining deductible items slowed considerably, since the Consumer Price Index rose by only 10 percent during the $1985-88$ period.

1988 to 1995 . Since 1988 , the total subsidy rate has crept back up slightly, from 15.3 percent to 16.1 percent. Both the average marginal corporate tax rate and the average marginal tax rate for itemizers also have increased slightly. The top corporate tax rate has been raised from 34 percent to 35 percent. A complicated set of inframarginal rates has been introduced that substantially raises the marginal tax rate for many smaller corporations, even above 35 percent in some cases. With respect to the individual income tax, brackets of 31 percent, 36 percent, and 39.6 percent have been introduced at the top end.

\section{Impact of Different Weighting Schemes on Average Marginal Tax Rate of Itemizers}

As shown in Table 1, column 7, the average marginal tax rate for itemizers, weighted by state and local taxes deducted, was 26.7 percent in 1995. The unweighted average, 21.4 percent, was much lower, reflecting the simple fact that state and local 
tax deductions tend to rise with income. If one uses the 21.4 percent value instead of 26.7 percent, the household subsidy rate for 1995 would have been only 3.9 percent instead of 7.2 percent, and the total tax subsidy rate would have been only 12.8 percent instead of 16.1 percent.

Note, also, the large impact of high-income households on these results. In 1995, the average marginal tax rate of itemizing households with adjusted gross income in excess of $\$ 200,000$ was 37 percent. Excluding these households lowers the tax rate of the nationwide average marginal itemizer from 26.7 percent to 23.5 percent, and the estimated household component from 7.2 percent to 5 percent (Table 1, bottom row, and Figure 1). This discrepancy is important in evaluating state-specific estimates of tax subsidy and tax price, which exclude high-income tax filers. In the interest of confidentiality, the state of residence of high-income filers is not revealed in publicly available tax file tapes. Since states' distributional characteristics differ considerably, the exclusion of high-income filers in state-specific estimates could be a serious source of bias.

\section{State-by-State Estimates}

State-by-state estimates of tax subsidy rates and their components are presented in Tables 2 and 3. As is the case for the nation as a whole, the business component is larger than the household component in every state except Maryland and Oregon. The economies of states with the highest business components tend to rely disproportionately on extractive industries and the severance and property taxes that these industries generate. Hence they also tend to rank among those states with the 
highest total tax subsidy rates. It should be noted that state-specific estimates for business share are for 1990, the latest year for which such estimates are available (Tannenwald 1993a, 1993b). In some states, such as Connecticut, which introduced a broad-based income tax for the first time in 1992, business's share has changed significantly. State and local taxes deducted as a percentage of total state and local household taxes are averages for state fiscal years 1992 and 1993.

The rank of a state's household component is highly correlated with both the propensity of its households to itemize and its ratio of deducted-to-total household taxes. Thus Maryland's and Oregon's propensities to itemize rank 1 and 2, respectively, while their ratios of deducted-to-total household taxes rank 2 and 1 , respectively. States with a high propensity to itemize tend to enjoy high average income, have expensive housing, and impose high income and/or property tax burdens.

\section{The Issue of User Fees and Charges}

Like all previous estimates of tax price and tax subsidy rates, the estimates provided in this paper fail to take into account user fees, charges, and other general purpose nontax revenues. These nontax sources accounted for 30 percent of all state and local general own-source revenues in 1992 and 1993. None of those payments made by households were deductible, while all of those payments made by businesses were deductible. Since the three largest sources of state and local user fees are schools, hospitals, and waste collection, probably at least 80 percent of them are not deductible. However, we really do not know the breakdown of fees and charges 
between businesses and households; disaggregating them in this fashion would make a useful contribution to research on the impact of deductibility.

\section{Impact of Eliminating Deductibility on Tax Subsidy Rate and Tax Price}

Any base-broadening tax proposal that would eliminate the deductibility of state and local income and property taxes would reduce the nationwide tax subsidy rate by the size of the household component, or by 7.2 cents on the dollar. As a result, the subsidy rate would fall from 16.1 percent to 9.0 percent, the size of the business component. The nationwide average tax price of state and local public goods and services would increase from $\$ .839$ to $\$ .911$, a percentage increase of 8.5 percent. The corresponding changes in state rates (again biased downward by the exclusion of high-income households) would range from 10.4 percent in Maryland to 0.9 percent in Wyoming (Table 4).

If tax price were computed solely on the basis of the household component, the elimination of deductibility would raise the nationwide tax price from $\$ .938$ to $\$ 1.00$, a percentage increase of 7.7 percent. Estimates of state-specific increases in tax price (once again biased by the absence of high-income taxpayers) would range from 9.6 percent in Maryland to 0.7 percent in Wyoming. Thus, in the aggregate, taking into account the deductibility of state and local business taxes raises the likely impact of the elimination of household tax deductibility, slightly but not by much.

Should the federal government eliminate its corporate profits tax, the implications for tax price would depend on how state and local taxes would be treated 
under the new federal tax regime. The impacts could be far more serious than those resulting from the elimination of the deductibility of state and local personal income and household property taxes. Consider, for example, the replacement of the federal corporate profits tax with a gross-up and credit value-added tax in which governmental services were not "in the loop." Under such conditions, the entire tax subsidy, including its business component, would disappear. The average nationwide tax price of state and local public goods would increase from $\$ .839$ to $\$ 1.00$, or approximately 19 percent. The impact on states that rely heavily on business taxes would be even larger.

\section{Summary and Suggestions for Further Research}

The media have showered much attention on the substantial future cuts in direct federal intergovernmental assistance advocated as part of the Contract with America. Less attention has been focused on the potential effect of federal tax reform on the subsidy enjoyed by state and local governments from the deductibility of a large portion of their taxes from federal taxable income. Both direct and indirect cuts in federal aid are being considered at a time when demand is growing for state and local services such as education, health care, and law enforcement. Especially in these circumstances, state and local policymakers need accurate estimates of the size of the tax subsidy they enjoy and how much federal tax reform would reduce it.

This paper shows that, when the deductibility of state and local business taxes from federal taxable corporate profits is taken into account, the subsidy is considerably 
larger than most analysts have previously believed. The estimate of the subsidy's magnitude becomes even larger when one weights itemizers' marginal federal tax rate by the amount of state and local taxes that he or she pays, rather than weighting each marginal tax rate equally or double-weighting jointly filed returns of married couples. As a result, federal tax reforms that would completely eliminate the subsidy could raise the tax price of state and local public goods by close to 20 percent.

How much would such state and local spending decline in response to a price increase of such a magnitude? In order to answer this question, one needs an estimate of the price elasticity of the demand for state and local public goods. Previous estimates have clustered between 0.25 and .50 (Courant and Rubinfeld 1987). However, they are based on measures of tax price that are flawed in ways analyzed in this paper. We need to go back to square one, reestimate tax prices by state accurately, and then reestimate the price elasticity of demand for state and local goods.

Unfortunately, the data required to do so are not readily available. Estimates of "business's share" of state and local taxes have been crude to begin with, given lack of timely, comprehensive, and comparable estimates across states of business's share of sales taxes and property taxes. What few data had been available to estimate business's share of property taxes are no longer collected by the U.S. Census Bureau. ${ }^{4}$ We need new data sources to improve our estimates of the business-household tax mix, if we are to accurately estimate tax prices.

${ }^{4}$ See ACIR (1981) and Tannenwald (1993a, 1993b) for a description of data and methodology used in estimating business's share. 


\section{APPENDIX}

In Tables 1 to 4 , data used in estimates were obtained from the following sources:

State and local taxes deducted by households.

1977, 1980, 1985, 1988.......U.S. Internal Revenue Service. Statistics of Income--Individual Tax Returns,

1995. Estimated from U.S. Internal Revenue Service, Public Use Tax File 1992, assuming 1995 Federal Tax Law

Average marginal federal income tax rate of itemizers, weighted by deduction for state and local taxes paid.

1977, 1980. Informal estimates provided by staff of Joint Committee on Taxation, U.S. Congress.

1985. Computed by National Bureau of Economic Research, using its TAXSIM Model.

1988. Computed by National Bureau of Economic Research using its TAXSIM Model, assuming 1988 law and based on 1985 tax data.

1995. Computed from U.S. Internal Revenue Service Public Use Tax File 1992 assuming 1995 federal tax law.

Average marginal federal corporate profits tax rate. All years.

Unofficial estimates provided by officials from U.S. Joint Committee on Taxation and Office of Tax Analysis, U.S. Department of the Treasury.

For 1995 state-specific estimates, marginal federal corporate profits tax rate in each state was assumed to be national average.

Business's Share of State and Local Taxes, for U.S. and by State.

1977--U.S. ACIR (1981) 
1980--Reschovsky et al. (1983).

1985--Commonwealth of Massachusetts (1987), estimated for 1984. Value for 1984 was used as proxy for 1985 value

1988 and 1995--Tannenwald (1993a, 1993b). Value estimated was for 1990.

This value was used for both 1988 and 1995.

1995 estimates of tax subsidy rate are based on 1992 tax data and assume 1995

law. 1990 is the latest year for which estimates of business's share are

available. It was assumed that nationwide values for business's share did not change significantly between 1988 and 1992. 


\section{REFERENCES}

Bergstrom, T. and R. Goodman. 1973. "Private Demand for Public Goods." The American Economic Review, vol. 63, no. 2, pp. 286-96.

Borchering, T.E. and R.T. Deacon. 1962. "The Demand for the Services of Nonfederal Governments." The American Economic Review, vol. 52, no. 4, pp. 891-901.

Clotfelter, Charles T. and Dan Feenberg. 1990. "Is There a Regional Bias in Federal Tax Subsidy Rates for Giving?" Journal of Public Finance, ?

Commonwealth of Massachusetts. 1987. The Eighth Interim Report of the Special Commission Relative to the Competitiveness of the Massachusetts Tax System in the Development of a Tax Reform Program for the Commonwealth. Boston.

Courant, Paul N., and Daniel R. Rubinfeld. 1987. "Tax Reform: Implications for the State-Local Sector." Journal of Economic Perspectives, vol. 1, no. 1, pp. 87100. Summer.

Feldstein, Martin S. and Gilbert E. Metcalf. 1987. "The Effect of Federal Tax Deductibility on State and Local Taxes and Spending." Journal of Political Economy, vol. 95, no. 4, pp. 710-36.

Gramlich, Edward M. 1985. "The Deductibility of State and Local Taxes." National Tax Journal, vol. 38, no. 4, pp. 447-65.

Inman, Robert P. 1986. "Markets, Government, and the 'New' Political Economy." In Alan J. Auerbach and Martin S. Feldstein, eds., Handbook of Public Economics, vol. 2. Amsterdam: North Holland.

Kenyon, Daphne A. 1986. "Federal Tax Deductibility of State and Local Taxes." In U.S. Office of State and Local Finance, Department of the Treasury, FederalState-Local Fiscal Relations: Technical Papers, vol. 1, pp. 417-96. September.

Reschovsky, Andrew, Gregory Topakian, Francoise Carre, Randall Crane, Peter Miller, and Paul Smoke. 1983. State Tax Policy: Evaluating the Issues. Cambridge, MA: Joint Center for Urban Studies of MIT and Harvard University. 
Tannenwald, Robert. 1989. "The Changing Level and Mix of Federal Aid to State and Local Governments." New England Economic Review, May/ June, pp. 41-55.

1993a. Massachusetts' Tax Competitiveness. Working paper prepared for the Massachusetts Special Commission on Business Tax Policy. Boston: Federal Reserve Bank of Boston, April 15.

. 1993b. "Can Massachusetts Compete?" Tax Notes, vol. 4, no. 22, pp. 12981317. May 31.

U.S. Advisory Commission on Intergovernmental Relations. 1981. Regional Growth: Interstate Tax Competition, Report A-76. Washington, DC.

U.S. Bureau of the Census. Various years. Governmental Finances. Washington, DC: Government Printing Office.

. Various years. Statistical Abstract of the United States. Washington, DC: Government Printing Office.

U.S. Internal Revenue Service. 1995a (and various other years). Statistics of Income-Individual Income Tax Returns 1992, Publication 1304. Washington, DC.

- 1995b. Statistics of Income--Corporation Income Tax Returns 1992, Publication 16. Washington, DC.

. 1996. 1992 Public Use Tax File (machine-readable data). Prepared by the University of Michigan School of Business.

Zimmerman, Dennis. 1983. "Resource Misallocation from Interstate Tax Exportation: Estimates of Excess Spending and Welfare Loss in a Median Voter Framework." National Tax Journal, vol. 36, no. 2, pp. 183-201. 


\section{Figure 1}

Marginal Subsidy Rate Attributable to Federal Deduction for State and Local Taxes, United States, Selected Years

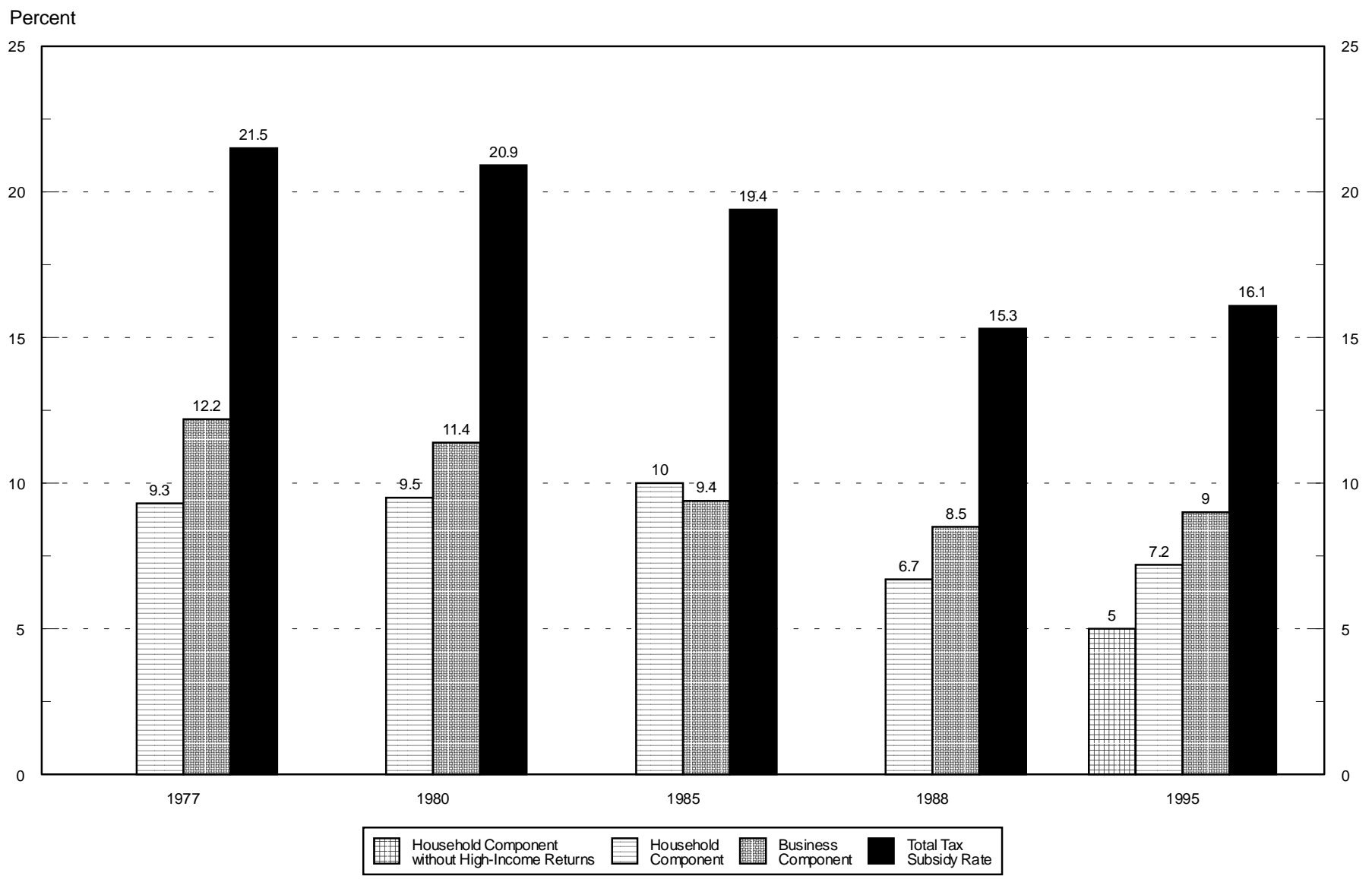

Note: Totals may not equal the sums of components because of rounding.

Note: In the computation of the 1995 household component, tax deductions for taxes other than state and local personal income

and real estate taxes were not available. The omitted taxes account for only a small fraction of all deducted taxes.

Source: Author's calculations; Internal Revenue Service, Statistics of Income: Individual Income Tax Returns, various years,

1992 Public Use Tax File; U.S. Bureau of the Census, Governmental Finances, various years. 


\section{Figure 2}

Percentage Increase in the Federal Standard Deductions and in the Average Outlay per Household on Selected Deductible Items, 1977 to 1985

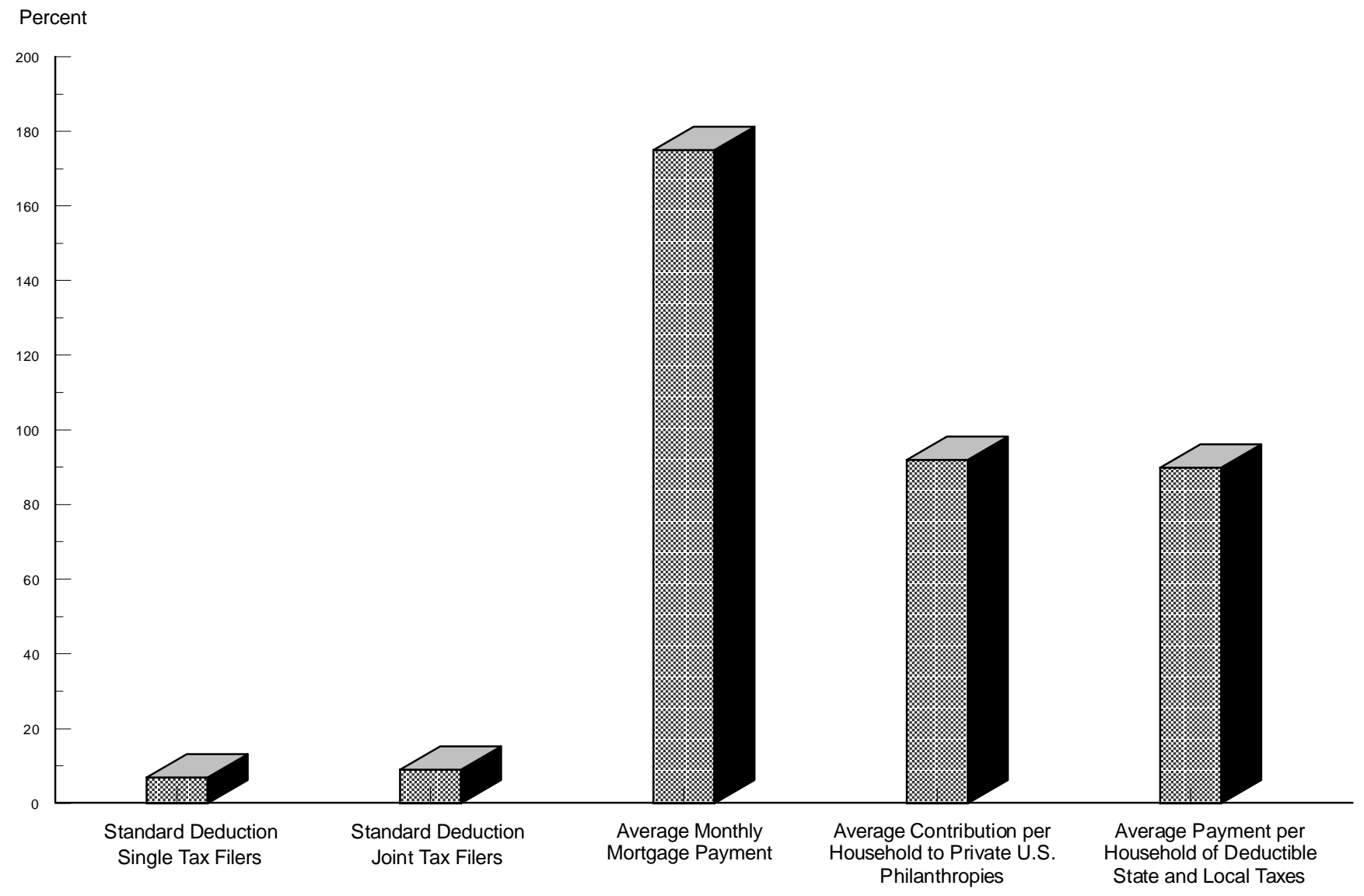

Source: Author's calculations; Internal Revenue Code of 1954, as Amended; U.S. Internal Revenue Service, Statistics of Income, Individual Income Tax Returns, various years; and U.S. Bureau of the Census, Statistical Abstract of the United States, various years. 
Table 1

Historical Tax Subsidy Rates, Selected Years

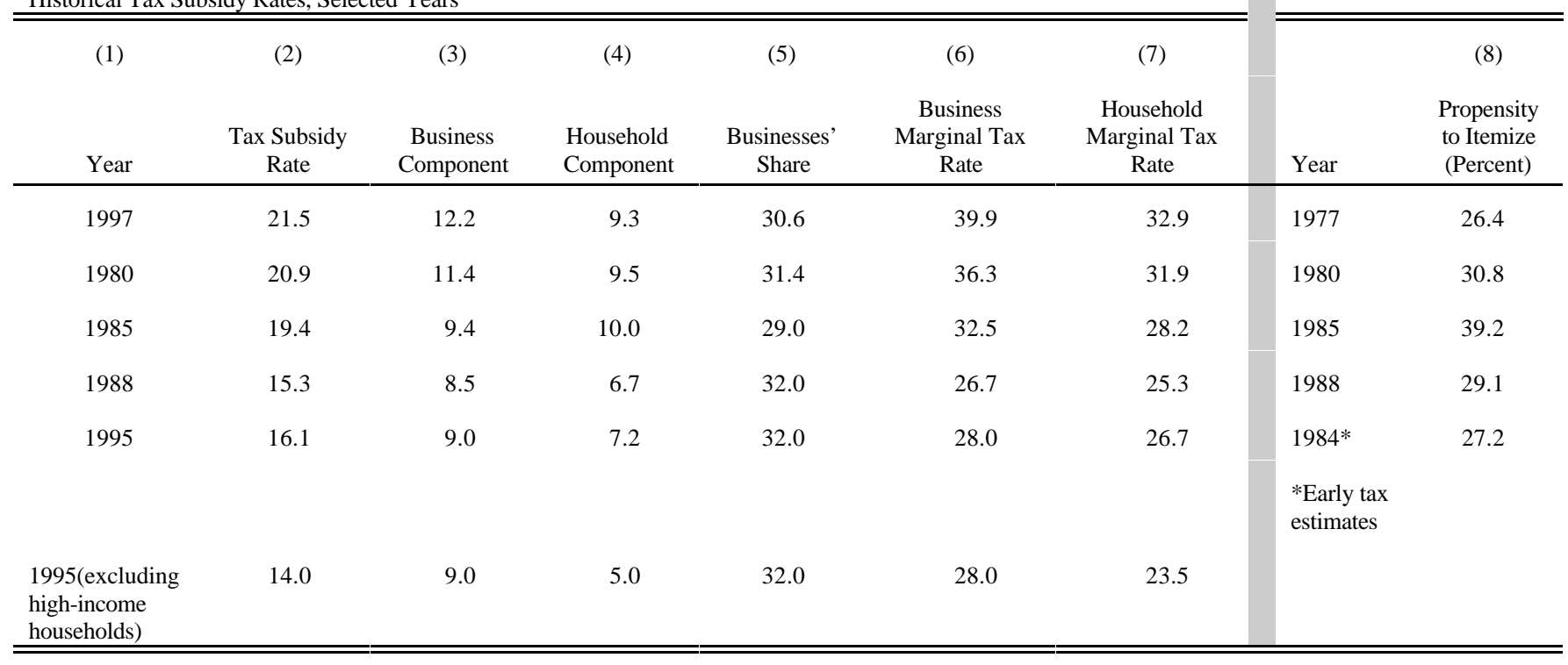

Note: Totals may not equal the sums of components because of rounding. In the computation of the 1995 household component, tax deductions for taxes other than state and local personal income and real estate taxes were not available.

These are mostly taxes on personal property and account for only a small fraction of all deducted taxes.

Source: See Figure 1 and the Appendix. 
Table 2

Tax Subsidy Rates, by State, 1995 (Percent)

\begin{tabular}{|c|c|c|c|c|c|c|c|c|}
\hline & (1) & (2) & & (3) & (4) & & (5) & (6) \\
\hline State & $\begin{array}{c}\text { Tax } \\
\text { Subsidy Rate }\end{array}$ & Rank & & $\begin{array}{c}\text { Household } \\
\text { Componen } \\
\mathrm{t}\end{array}$ & Rank & & $\begin{array}{c}\text { Business } \\
\text { Component (1990) }\end{array}$ & Rank \\
\hline U.S. Average & 16.1 & & & 7.2 & & & 9.0 & \\
\hline $\mathrm{AK}$ & 22.9 & 1 & MD & 8.8 & 1 & $\mathrm{AK}$ & 22.1 & 1 \\
\hline WY & 20.2 & 2 & OR & 8.1 & 2 & WY & 19.4 & 2 \\
\hline $\mathrm{DE}$ & 18.7 & 3 & NJ & 7.3 & 3 & MT & 14.4 & 3 \\
\hline MT & 17.0 & 4 & VA & 6.9 & 4 & LA & 12.9 & 4 \\
\hline OR & 16.1 & 5 & MA & 6.9 & 4 & $\mathrm{DE}$ & 12.8 & 5 \\
\hline MD & 16.1 & 5 & $\mathrm{MN}$ & 6.7 & 6 & $\mathrm{TX}$ & 12.4 & 6 \\
\hline KY & 15.9 & 7 & WI & 6.6 & 7 & WV & 12.3 & 7 \\
\hline NJ & 15.8 & 8 & MI & 6.5 & 8 & KY & 10.8 & 8 \\
\hline $\mathrm{NH}$ & 15.5 & 9 & RI & 6.1 & 9 & KS & 10.6 & 9 \\
\hline $\mathrm{CT}$ & 15.4 & 10 & NY & 6.1 & 9 & $\mathrm{NH}$ & 10.4 & 10 \\
\hline MI & 15.3 & 11 & $\mathrm{CT}$ & 6.0 & 11 & $\mathrm{FL}$ & 10.2 & 11 \\
\hline VA & 15.3 & 11 & VT & 5.9 & 12 & $\mathrm{AL}$ & 9.9 & 12 \\
\hline KS & 15.3 & 11 & $\mathrm{DE}$ & 5.9 & 12 & NM & 9.8 & 13 \\
\hline NY & 15.1 & 14 & $\mathrm{CO}$ & 5.7 & 14 & $\mathrm{TN}$ & 9.7 & 14 \\
\hline $\mathrm{SC}$ & 14.5 & 15 & $\mathrm{CA}$ & 5.6 & 15 & MS & 9.5 & 15 \\
\hline LA & 14.5 & 15 & $\mathrm{SC}$ & 5.6 & 15 & ND & 9.4 & 16 \\
\hline $\mathrm{CA}$ & 14.4 & 17 & $\mathrm{OH}$ & 5.4 & 17 & $\mathrm{CT}$ & 9.4 & 16 \\
\hline $\mathrm{TX}$ & 14.3 & 18 & GA & 5.2 & 18 & WA & 9.4 & 16 \\
\hline WV & 14.1 & 19 & IA & 5.2 & 18 & $\mathrm{AZ}$ & 9.4 & 16 \\
\hline $\mathrm{CO}$ & 14.0 & 20 & KY & 5.1 & 20 & $\mathrm{OK}$ & 9.3 & 20 \\
\hline $\mathrm{PA}$ & 13.8 & 21 & UT & 5.0 & 21 & NV & 9.2 & 21 \\
\hline $\mathrm{MN}$ & 13.7 & 22 & NH & 5.0 & 21 & NY & 9.0 & 22 \\
\hline $\mathrm{OH}$ & 13.7 & 22 & PA & 4.8 & 23 & PA & 8.9 & 23 \\
\hline VT & 13.6 & 24 & $\mathrm{ME}$ & 4.8 & 23 & $\mathrm{SC}$ & 8.9 & 23 \\
\hline UT & 13.4 & 25 & KS & 4.7 & 25 & MI & 8.8 & 25 \\
\hline $\mathrm{OK}$ & 13.3 & 26 & $\mathrm{IL}$ & 4.7 & 25 & $\mathrm{CA}$ & 8.8 & 25 \\
\hline IL & 13.2 & 27 & $\mathrm{NC}$ & 4.6 & 27 & MO & 8.7 & 27 \\
\hline RI & 13.1 & 28 & ID & 4.2 & 28 & IL & 8.5 & 28 \\
\hline $\mathrm{AZ}$ & 13.0 & 29 & MO & 4.1 & 29 & $\mathrm{NJ}$ & 8.5 & 28 \\
\hline MA & 12.9 & 30 & $\mathrm{NE}$ & 4.0 & 30 & VA & 8.4 & 30 \\
\hline ND & 12.9 & 30 & $\mathrm{OK}$ & 3.9 & 31 & UT & 8.3 & 31 \\
\hline $\mathrm{AL}$ & 12.8 & 32 & IN & 3.9 & 31 & $\mathrm{CO}$ & 8.3 & 31 \\
\hline MO & 12.8 & 32 & $\mathrm{AZ}$ & 3.7 & 33 & $\mathrm{OH}$ & 8.3 & 31 \\
\hline GA & 12.8 & 32 & AR & 3.6 & 34 & OR & 8.0 & 34 \\
\hline NM & 12.7 & 35 & HI & 3.5 & 35 & $\mathrm{NC}$ & 7.8 & 35 \\
\hline WI & 12.6 & 36 & ND & 3.4 & 36 & IN & 7.7 & 36 \\
\hline FL & 12.4 & 37 & NM & 3.0 & 37 & VT & 7.7 & 36 \\
\hline $\mathrm{NC}$ & 12.4 & 37 & $\mathrm{AL}$ & 2.9 & 38 & SD & 7.6 & 38 \\
\hline MS & 11.7 & 39 & MT & 2.6 & 39 & GA & 7.5 & 39 \\
\hline $\mathrm{ME}$ & 11.6 & 40 & MS & 2.3 & 40 & HI & 7.3 & 40 \\
\hline IN & 11.6 & 40 & FL & 2.2 & 41 & MD & 7.3 & 40 \\
\hline WA & 11.6 & 40 & WA & 2.2 & 41 & AR & 7.3 & 40 \\
\hline ID & 11.3 & 43 & $\mathrm{TX}$ & 1.9 & 43 & ID & 7.1 & 43 \\
\hline NV & 10.9 & 44 & WV & 1.8 & 44 & MN & 7.0 & 44 \\
\hline AR & 10.9 & 44 & NV & 1.7 & 45 & RI & 6.9 & 45 \\
\hline IA & 10.9 & 44 & LA & 1.6 & 46 & $\mathrm{ME}$ & 6.8 & 46 \\
\hline $\mathrm{TN}$ & 10.9 & 44 & $\mathrm{TN}$ & 1.1 & 47 & $\mathrm{NE}$ & 6.2 & 47 \\
\hline $\mathrm{HI}$ & 10.8 & 48 & SD & 1.0 & 48 & MA & 6.0 & 48 \\
\hline $\mathrm{NE}$ & 10.2 & 49 & AK & 0.8 & 49 & WI & 6.0 & 48 \\
\hline $\mathrm{SD}$ & 8.5 & 50 & $\mathrm{WY}$ & 0.7 & 50 & $\mathrm{IA}$ & 5.7 & 50 \\
\hline
\end{tabular}

${ }^{a}$ U.S. average includes high-income tax filers. State-by-state figures exclude high-income filers. 
Table 3

Tax Subsidy Rates by State, 1995 , and Related Statistics (Percent)

(1)

(2)

$\begin{array}{cccc}\text { State } & \text { Tax } & \text { Household } & \text { Business } \\ \text { Subsidy } & \text { Componen } \\ \text { Rate } & t & \text { Componen } \\ & & 1 & 1990)\end{array}$

AL

$\mathrm{AK}$

$\mathrm{AZ} \quad 13.0$

AR $\quad 10.9$

CA $\quad 14.4$

$\mathrm{CO} \quad 14.0$

CT $\quad 15.4$

$\mathrm{DE} \quad 18.7$

$\begin{array}{ll}\text { DC } & \text {. } \\ \text { FL } & 12.4\end{array}$

$\begin{array}{ll}\text { FL } & 12.4 \\ \text { GA } & 12.8\end{array}$

$\mathrm{HI} \quad 10.8$

ID $\quad 11.3$

IL $\quad 13.2$

IN $\quad 11.6$

IA $\quad 10.9$

KS $\quad 15.3$

$\begin{array}{ll}\text { KY } & 15.9\end{array}$

LA $\quad 14.5$

ME $\quad 11.6$

MD $\quad 16.1$

MA $\quad 12.9$

MI $\quad 15.3$

$\begin{array}{ll}\text { MN } & 13.7\end{array}$

MS $\quad 11.7$

MO $\quad 12.8$

MT $\quad 17.0$

NE $\quad 10.2$

NV $\quad 10.9$

$\mathrm{NH} \quad 15.5$

NJ $\quad 15.8$

NM $\quad 12.7$

NY $\quad 15.1$

NC $\quad 12.4$

ND $\quad 12.9$

$\begin{array}{ll}\mathrm{OH} & 13.7\end{array}$

OK $\quad 13.3$

$\begin{array}{ll}\text { OR } & 16.1\end{array}$

$\begin{array}{ll}\text { PA } & 13.8\end{array}$

RI $\quad 13.1$

SC $\quad 14.5$

$\begin{array}{ll}\mathrm{SD} & 8.5\end{array}$

$\begin{array}{lr}\text { TN } & 10.9\end{array}$

TX $\quad 14.3$

UT $\quad 13.4$

VT $\quad 13.6$

VA $\quad 15.3$

WA $\quad 11.6$

WV $\quad 14.1$

WI 12.6

WY 202
(4)

Percent of State and Local Taxes

Filers

Itemizing
Deducted/(Total state

and local taxes*1-

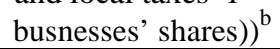

(6)

Average Marginal Tax

Rate for Itemizers

Weighted by State and Local Taxes Deducted

9.0
9.9

$22.1-19.1$

$\begin{array}{ll}9.4 & 32.3\end{array}$

$\begin{array}{ll}7.3 & 18.7\end{array}$

$\begin{array}{ll}8.8 & 33.4\end{array}$

$8.3 \quad 33.7$

$9.4 \quad 34.2$

$12.8 \quad 31.1$

5.9

\section{4}

\section{2}

\section{2}

\section{5}

4.2

4.7

3.9

\section{2}

\section{7}

\section{1}

1.6

4.8

\section{8}

6.9

\section{5}

\section{7}

\section{3}

4.1

2.6

\section{0}

\section{7}

\section{0}

\section{3}

3.0

\section{1}

\section{6}

\section{4}

\section{4}

\section{9}

\section{1}

4.8

6.1

5.6

$$
1.0
$$

$$
1.1
$$

1.9

5.0

5.9

6.9

2.2

1.8

6.6

07
10.2

10.2
7.5

7.3

7.1

8.5

7.7

5.7

10.6

10.8

12.9

6.8

7.3

6.0

8.8

7.0

9.5

8.7

14.4

6.2

9.2

10.4

8.5

9.8

9.0

7.8

9.4

8.3

9.3

8.0

8.9

6.9

8.9

7.6

9.7

12.4

8.3

7.7

8.4

9.4

12.3

6.0

19.4

39.4
19.3
15.2

26.7

23.6

23.8

23.1

24.6

23.6

23.3

24.3

23.9

24.2

22.1

23.5

23.5

23.3

23.8

23.0

22.5

24.5

23.3

25.3

22.4

23.6

23.7

22.9

24.1

23.6

23.0

21.7

22.4

22.6

21.7

23.8

24.5

24.2

22.9

24.0

24.4

22.9

21.7

23.2

22.5

23.3

19.2

22.4

23.4

21.4

22.2

24.4

22.2

24.0

23.6

224

${ }^{\mathrm{a}}$ U.S. average includes high-income tax filers. State-by-state figures exclude high-income filers.

${ }^{\mathrm{b}}$ Averages for state fiscal years 1992 and 1993.

Source: See the Appendix. 
Table 4

Percentage Change in Tax Subsidy Rate and Its Household Component Resulting from Elimination of Deductibility of State and Local Personal Income and Property Tax, by State, Assuming 1995 Law (Percent)

\begin{tabular}{|c|c|c|c|c|c|c|}
\hline State & \begin{tabular}{l}
\multicolumn{1}{c}{$(1)$} \\
Percentage Change in \\
Tax Subsidy Rate \\
[Household/(1-Tax \\
subsidy rate)]
\end{tabular} & $\begin{array}{c}(2) \\
\text { Rank }\end{array}$ & \begin{tabular}{l}
\multicolumn{1}{c}{ (3) } \\
Percentage Change in \\
Household Component \\
[Household Component/ \\
(1-Tax subsidy rate)]
\end{tabular} & $\begin{array}{c}(4) \\
\text { Rank }\end{array}$ & $\begin{array}{c}\text { (5) } \\
\text { Tax Subsidy } \\
\text { Rate }\end{array}$ & $\begin{array}{c}(6) \\
\text { Household } \\
\text { Component }\end{array}$ \\
\hline U.S. Average & 8.6 & & 7.8 & & 16.1 & 7.2 \\
\hline MD & 10.4 & 1 & 9.6 & 1 & 16.1 & 8.8 \\
\hline OR & 9.6 & 2 & 8.8 & 2 & 16.1 & 8.1 \\
\hline $\mathrm{NJ}$ & 8.7 & 3 & 7.9 & 3 & 15.8 & 7.3 \\
\hline VA & 8.1 & 4 & 7.4 & 4 & 15.3 & 6.9 \\
\hline MA & 7.9 & 5 & 7.4 & 4 & 12.9 & 6.9 \\
\hline MN & 7.7 & 6 & 7.1 & 6 & 13.7 & 6.7 \\
\hline MI & 7.7 & 6 & 7.0 & 8 & 15.3 & 6.5 \\
\hline WI & 7.6 & 8 & 7.1 & 6 & 12.6 & 6.6 \\
\hline $\mathrm{DE}$ & 7.2 & 9 & 6.3 & 12 & 18.7 & 5.9 \\
\hline NY & 7.2 & 9 & 6.5 & 9 & 15.1 & 6.1 \\
\hline RI & 7.1 & 11 & 6.5 & 9 & 13.1 & 6.1 \\
\hline CT & 7.1 & 11 & 6.4 & 11 & 15.4 & 6.0 \\
\hline VT & 6.8 & 13 & 6.3 & 12 & 13.6 & 5.9 \\
\hline $\mathrm{CO}$ & 6.6 & 14 & 6.1 & 14 & 14.0 & 5.7 \\
\hline $\mathrm{CA}$ & 6.6 & 14 & 6.0 & 15 & 14.4 & 5.6 \\
\hline $\mathrm{SC}$ & 6.5 & 16 & 5.9 & 16 & 14.5 & 5.6 \\
\hline $\mathrm{OH}$ & 6.3 & 17 & 5.7 & 17 & 13.7 & 5.4 \\
\hline KY & 6.1 & 18 & 5.4 & 20 & 15.9 & 5.1 \\
\hline GA & 6.0 & 19 & 5.5 & 18 & 12.8 & 5.2 \\
\hline $\mathrm{NH}$ & 5.9 & 20 & 5.3 & 21 & 15.5 & 5.0 \\
\hline IA & 5.8 & 21 & 5.5 & 18 & 10.9 & 5.2 \\
\hline UT & 5.8 & 21 & 5.3 & 21 & 13.4 & 5.0 \\
\hline PA & 5.6 & 23 & 5.1 & 23 & 13.8 & 4.8 \\
\hline KS & 5.5 & 24 & 4.9 & 25 & 15.3 & 4.7 \\
\hline $\mathrm{ME}$ & 5.4 & 25 & 5.1 & 23 & 11.6 & 4.8 \\
\hline $\mathrm{IL}$ & 5.4 & 25 & 4.9 & 25 & 13.2 & 4.7 \\
\hline $\mathrm{NC}$ & 5.3 & 27 & 4.8 & 27 & 12.4 & 4.6 \\
\hline ID & 4.8 & 28 & 4.4 & 28 & 11.3 & 4.2 \\
\hline MO & 4.8 & 28 & 4.3 & 29 & 12.8 & 4.1 \\
\hline OK & 4.5 & 30 & 4.1 & 30 & 13.3 & 3.9 \\
\hline $\mathrm{NE}$ & 4.4 & 31 & 4.1 & 30 & 10.2 & 4.0 \\
\hline IN & 4.4 & 31 & 4.0 & 32 & 11.6 & 3.9 \\
\hline AZ & 4.2 & 33 & 3.8 & 33 & 13.0 & 3.7 \\
\hline AR & 4.1 & 34 & 3.8 & 33 & 10.9 & 3.6 \\
\hline ND & 3.9 & 35 & 3.6 & 35 & 12.9 & 3.4 \\
\hline $\mathrm{HI}$ & 3.9 & 35 & 3.6 & 35 & 10.8 & 3.5 \\
\hline NM & 3.4 & 37 & 3.0 & 37 & 12.7 & 3.0 \\
\hline $\mathrm{AL}$ & 3.4 & 37 & 3.0 & 37 & 12.8 & 2.9 \\
\hline MT & 3.1 & 39 & 2.7 & 39 & 17.0 & 2.6 \\
\hline MS & 2.6 & 40 & 2.3 & 40 & 11.7 & 2.3 \\
\hline FL & 2.5 & 41 & 2.3 & 40 & 12.4 & 2.2 \\
\hline WA & 2.5 & 41 & 2.3 & 40 & 11.6 & 2.2 \\
\hline $\mathrm{TX}$ & 2.2 & 43 & 1.9 & 43 & 14.3 & 1.9 \\
\hline WV & 2.1 & 44 & 1.9 & 43 & 14.1 & 1.8 \\
\hline $\mathrm{NV}$ & 1.9 & 45 & 1.7 & 45 & 10.9 & 1.7 \\
\hline LA & 1.9 & 45 & 1.6 & 46 & 14.5 & 1.6 \\
\hline $\mathrm{TN}$ & 1.3 & 47 & 1.2 & 47 & 10.9 & 1.1 \\
\hline SD & 1.1 & 48 & 1.0 & 48 & 8.5 & 1.0 \\
\hline AK & 1.0 & 49 & 0.8 & 49 & 22.9 & 0.8 \\
\hline WY & 0.9 & 50 & 0.7 & 50 & 20.2 & 0.7 \\
\hline
\end{tabular}

${ }^{a}$ U.S. average includes high-income tax filers. State-by-state figures exclude high-income filers.

Source: See the Appendix. 